\title{
Comparative evaluation of flavone from Mucuna pruriens and coumarin from lonidium suffruticosum for hypolipidemic activity in rats fed with high Fat diet
}

\author{
Satheesh Kumar Dharmarajan and Kottai Muthu Arumugam*
}

\begin{abstract}
The objective of the study is a comparative evaluation of flavone isolated from Mucuna pruriens and coumarin isolated from lonidium suffruticosum was assessed for the hypolipidemic activity in rats fed with high fat diet. The acute toxicity study was found that flavone (M.pruriens) and coumarin (I.suffruticosum) are safe up to 100 mg/kg, so one tenth of this dose $(10 \mathrm{mg} / \mathrm{kg})$ was consider as a evaluation dose. High fat diet group of rats showed significant $(p<0.001)$ elevation in plasma total and LDL-cholesterol, triglycerides and phospholipids. Administration of flavone (M. pruriens) and coumarin isolated from (I.suffruticosum) at the dose of $10 \mathrm{mg} / \mathrm{kg}$ b.wt/day along with high fat diet significantly $(p<0.001)$ prevented the rise in the plasma total and LDL-cholesterol, triglycerides and phospholipids than that of other extracts. However, treatment of coumarin isolated from (I.suffruticosum) had showed more cardio protective effect against hyperlipidemia than that of flavone (M.pruriens).
\end{abstract}

Keywords: M. pruriens, I.suffruticosum, Flavone, Coumarin, Hyperlipidemia

\section{Introduction}

Cardiovascular disease is a major problem worldwide. The World Health Organization estimates that this disease is responsible for the deaths of approximately 30,000 people each day [1]. Hyperlipidaemia is characterized by elevated serum total cholesterol, low-density lipoprotein cholesterol, very low density lipoprotein cholesterol and decreased high-density lipoprotein cholesterol levels [2]. As reported in literature synthetic drugs may be having serious side effects [3]. Statins may also be associated with some other rarely occurring side effects like nausea, abdominal pain, dyspepsia, diarrhoea or constipation and flatulence [4]. Medicinal plants, on the other hand, have been reported safer as compared topharmaceutically derived remedies [2].

Mucuna pruriens Linn belongs to the family fabaceae, traditionally in India the seeds of Mucuna pruriens are used as a tonic and aphrodisiac for male virility. It has been reported to be antidiabetic [5], analgesic and anti-

\footnotetext{
* Correspondence: arthik03@yahoo.com

Department of Pharmacy, Annamalai University, Annamalai, Nagar 608 002, India
}

\section{() Biomed Central

(C) 2012 Kumar and Muthu; licensee BioMed Central Ltd. This is an Open Access article distributed under the terms of the Creative Commons Attribution License (http://creativecommons.org/licenses/by/2.0), which permits unrestricted use, distribution, and reproduction in any medium, provided the original work is properly cited. inflammatory [6]. Its different preparations (from seeds) are used for the management of several free radicalmediated diseases such as ageing, rheumatoid arthritis, diabetes, atherosclerosis, male infertility and nervous disorders. Ionidium suffruticosum (Ging.) it belongs to the family Violaceae, it is widely used as traditional healers for the treatment of diseases like diabetes [7], male sterility [8], urinary tract infections and water retention [9]. Hence, the attempt is made for the comparative evaluation of flavone from Mucuna pruriens and Coumarin isolated from Ionidium suffruticosum for hypolipidemic activity in rats fed with high fat diet.

\section{Materials and methods}

Collection and identification of plant materials

The whole plant of Mucuna pruriens (Linn), were collected from Neiyur dam, Kanyakumari District of Tamil $\mathrm{Nadu}$, India and the whole plant of Ionidium suffruticosum (Ging) were collected from Kilikulam, Tirunelveli District of Tamil Nadu, India. The taxonomic identification was made from Botanical Survey of Medicinal Plants Unit Siddha, Government of India, Palayamkottai. 
The whole plant of Mucuna pruriens (Linn) and Ionidium suffruticosum (Ging) were dried under shade, segregated, pulverized by a mechanical grinder and passed through a 40 mesh sieve. The powdered plant materials were stored in an airtight container.

\section{Chemicals}

All the chemicals used in the study were of analytical grade, procured from the credible concerns e.g.: Sigma, Merck and Qualigens. Atorvastatin was provided as a generous gift sample by Ranbaxy Pharmaceuticals, India.

\section{Preparation of various extracts from Mucuna pruriens and ionidium suffruticosum}

The whole plant of Mucuna pruriens (Linn) and Ionidium suffruticosum (Ging) were dried in shade and powdered. The powdered plant materials were successively extracted with petroleum ether $\left(40-60^{\circ} \mathrm{C}\right)$ by hot continuous percolation method in Soxhlet apparatus [10] for 24 hrs. Then the marc was dried and then subjected to ethyl acetate $\left(76-78^{\circ} \mathrm{C}\right)$ for $24 \mathrm{hrs}$, then marc was dried and then it was subjected to methanol $\left(80^{\circ} \mathrm{C}\right)$ for 24 hrs. The solvent from the extracts was recovered under reduced pressure using rotary evaporator and subjected to freeze drying in a lyophilizer till dry powder was obtained.

\section{Isolation of flavone from methanol extract of Mucuna pruriens}

The methanol extract of Mucuna pruriens was subjected to column chromatographic separation using normal phase silica gel column. The dark brown solid (20 g methanol extract of Mucuna pruriens) was adsorbed on silica gel $(20 \mathrm{~g})$ and transferred to a column of silica gel (200g equilibrated with benzene). Flavone (265mg) was eluted with ethyl acetate: methanol, 80:20 v/v from methanol extract of Mucuna pruriens.

\section{Isolation of coumarin from methanolic extract of ionidium suffruticosum}

The methanolic extract of Ionidium suffruticosum was subjected to column chromatographic separation using normal phase silica gel column. The dark brown solid (20 g methanolic extract of Ionidium suffruticosum) was adsorbed on silica gel ( $20 \mathrm{~g}$ ) and transferred to a column of silica gel (200g equilibrated with benzene). The Coumarin derivative $(245 \mathrm{mg}$ ) was eluted with benzene: Chloroform 70:30, v/v from methanolic extract of Ionidium suffruticosum.

\section{Experimental animals}

Healthy male Wistar rats (weighing 120-150g) were procured from Central Animal House, Rajah Muthiah Medical College, Annamalai University. The animals were kept in cages, 2 per cage, with relative humidity (55\%) in a 12 hour light/dark cycle at $25 \pm 2^{\circ} \mathrm{C}$. They were given access to water and a commercial diet ad libitum. The experiment were carried out as per the guidelines of Committee for the Purpose of Control and Supervision of Experiments on Animals (CPCSEA), New Delhi, India, and approved by the Institutional Animal Ethics Committee (IAEC), Annamalai University (Approved number: 160/1999/CPCSEA/745).

\section{Acute toxicity studies}

Acute oral toxicity study was performed as per Organization and Economic Cooperation and Development (OECD) guidelines 423 adopted on $17^{\text {th }}$ December 2001 received from Committee for the purpose of Control and Supervision of Experimental Animals (CPCSEA). The rats were fed with flavone from Mucuna pruriens and Coumarin derivatives from Ionidium suffruticosum suspended in $1 \%$ gum acacia at the dose of $100 \mathrm{mg} / \mathrm{kg}$ body weight. The animals were observed individually every 30 minutes after dosing the first $24 \mathrm{hrs}$ and thereafter daily for a total of 14 days. The time at which signs of toxicity appear and disappear was observed systematically and recorded for each animal.

\section{Experimental induction of hyperlipidemia}

High fat diet was prepared by mixing Wheat flour $20.5 \%$, roasted bengal gram $52.6 \%$, skimmed milk powder $5 \%$, casein $4 \%$, refined oil $4 \%$, coconut oil $9 \%$, salt mixture with starch $4 \%$ and vitamin \& choline mixture $0.5 \%$, cholesterol $0.4 \%$ [11]. The diet was placed in the cage carefully and was administered for 14 days [12].

\section{Protocol for antihyperlipidemic activity}

In the experiment a total number of 36 rats were used. The rats were divided into five groups of six each. Group I: control, Group II: High Fat Diet (HFD), Group III: HFD plus Flavone (M. pruriens) at the dose of $10 \mathrm{mg} / \mathrm{kg}$ b.wt, Group IV: HFD plus Coumarin (I. suffruticosum) at the dose of $10 \mathrm{mg} / \mathrm{kg}$ b.wt, Group V: HFD + standard drug atorvastatin $(1.2 \mathrm{mg} / \mathrm{kg}$ b.wt). The drugs were suspended in $2 \%$ tween 80 [13] separately and fed to the respective rats by oral intubation. At the end of the study all the rats were sacrificed by cervical dislocation after overnight fasting. Just before sacrifice, blood was collected from the retro-orbital sinus plexus under mild ether anaesthesia and blood sample collected in heparinised tubes and plasma was separated. Liver, heart and aorta were cleared of adhering fat, weighed accurately and used for the preparation of homogenate. Animals were given enough care as per the Animal Ethical Committee's recommendations. 
Table 1 Average Body weight changes in control and experimental rats

\begin{tabular}{llll}
\hline Groups & Initial Weight $(\mathbf{g})$ & Final Weight $(\mathbf{g})$ & Average Body weight gain (g) \\
\hline Group I & $137.34 \pm 0.47^{\mathrm{bNS}}$ & $156.66 \pm 2.47^{\mathrm{b}^{*}}$ & $19.32 \pm 2.39^{\mathrm{b}^{*}}$ \\
\hline Group II & $136.33 \pm 0.42^{\mathrm{aNS}}$ & $198.64 \pm 2.58^{\mathrm{a}^{*}}$ & $62.31 \pm 1.90^{\mathrm{a}^{*}}$ \\
\hline Group III & $136.71 \pm 0.41^{\mathrm{aNS}, \mathrm{bNS}}$ & $162.33 \pm 2.16^{\mathrm{aNS}, \mathrm{b}^{* *}}$ & $25.62 \pm 2.54^{\mathrm{aNS}, \mathrm{b}^{*}}$ \\
\hline Group IV & $136.57 \pm 0.53^{\mathrm{aNS}, \mathrm{bNS}}$ & $161.26 \pm 1.38^{\mathrm{aNS}, \mathrm{b}^{*}}$ & $24.69 \pm 3.28^{\mathrm{aNS}, \mathrm{b}^{*}}$ \\
\hline Group V & $137.55 \pm 0.74^{\mathrm{aNS}, \mathrm{bNS}}$ & $161.51 \pm 1.74^{\mathrm{aNS}, \mathrm{b}^{*}}$ & $23.96 \pm 3.39^{\text {aNS, }}$ \\
\hline
\end{tabular}

Values are expressed as mean \pm SE ( $=6$ rats); $P$ values: ${ }^{*}<0.001,{ }^{* *}<0.05$; NS: Non significant; $a \rightarrow$ group I compared with groups II, III, IV\& V; $\rightarrow$ group II compared with groups III, IV\& V; Group I : Standard chow diet (Control); Group II : High Fat Diet (Negative Control); Group III : HFD + Flavone (M.pruriens) (10mg/kg b.wt); Group IV : HFD+Coumarin (I. suffruticosum) (10mg/kg b.wt); Group V : HFD + Atorvastatin (1.2 mg/kg b.wt) (Positive Control).

\section{Biochemical analysis}

Plasma samples were analyzed for total cholesterol, HDL-cholesterol and triglycerides using Boehringer Mannheim kits by Erba Smart Lab analyzer USA. LDLcholesterol and VLDL-cholesterol were calculated by using Friedwald method [14]. Ester cholesterol [15] and free cholesterol [15] were analyzed by using digitonin. Portions of liver, heart and aorta tissues were blotted, weighed and homogenized with methanol (3 volumes) and the lipid extracts were obtained by the method of Folch et al. (1957) [16]. Extracts were used for the estimation of ester cholesterol and free cholesterol, triglycerides [17], and phospholipids [18]. The atherogenic Index was calculated by using the following formula.

$$
\text { Athorogenic Index }=\frac{\text { Total cholesterol }}{H D L}
$$

\section{Statistical analysis}

Results were expressed as mean \pm SE of 6 rats in each group. The data were also analysed by one way analysis of variance (ANOVA) followed by Dunnet's t-test. 'P, value less than 0.05 is considered significant.

\section{Results and discussion}

Balance between synthesis and degradation of biological tissues is maintained by Lipid metabolism. Development of hyperlipidemia disease is a complicated process involving accumulation of lipid containing particles in the walls of coronary arteries \& other major arteries within the body. A high-fat diet causes cholesterol levels to increase in susceptible people, which leads to obesity.

The flavone isolated from Mucuna pruriens and coumarin derivatives isolated from Ionidium suffruticosum were found to be non-toxic upto the dose of $100 \mathrm{mg} / \mathrm{kg}$ and did not cause any death of the tested animals. Therefore, one tenth of this dose $(10 \mathrm{mg} / \mathrm{kg})$ was considered as the evaluation dose. As shown in Table 1, the weight gain in HFD group of rats significantly $(\mathrm{p}<0.001)$ higher than control rats reflecting the influence of high fat diet. The increment in the weight reduced significantly $(\mathrm{p}<0.001)$ by the administration of flavone from (M.pruriens) (Group III) and Coumarin (I. suffruticosum) (Group IV) at the dose of $10 \mathrm{mg} / \mathrm{kg}$ as well as atorvastatin $1.2 \mathrm{mg} / \mathrm{kg}$ in comparison with the HFD fed rats (Group II). Administration of Coumarin (I. suffruticosum) at the dose of $10 \mathrm{mg} / \mathrm{kg}$ exhibited the significant reduction in bodyweight in comparison with the group received flavone ( $M$. pruriens) (Group III). The weight reducing effect may be attributed to its potential to inhibit lipogenesis and enhanced thermogenesis, since obesity is associated with defective thermogenesis [19].

As shown in Table 2, HFD rats are showed significant increase $(\mathrm{p}<0.001)$ in plasma total cholesterol level as compared to control rats (group I). Earlier studies reveal significant elevation of lipid parameters in plasma and tissue response to atherogenic diet or high fat diet $[20,21]$. Treatment with flavone isolated from Mucuna pruriens and coumarin derivatives isolated from Ionidium suffruticosum at the dose of $10 \mathrm{mg} / \mathrm{kg}$ body weight

Table 2 Effect of flavone from Mucuna pruriens and coumarin from Ionidium suffruticosum on plasma lipid profile in control and experimental rats

\begin{tabular}{lcccccc}
\hline Groups & $\begin{array}{l}\text { Total cholesterol } \\
(\mathbf{m g} / \mathbf{d l})\end{array}$ & $\begin{array}{l}\text { Free cholesterol } \\
(\mathbf{m g} / \mathbf{d} \mathbf{l})\end{array}$ & $\begin{array}{l}\text { Ester cholesterol } \\
(\mathbf{m g} / \mathbf{d l})\end{array}$ & $\begin{array}{l}\text { Phospholipid } \\
(\mathbf{m g} / \mathbf{d l})\end{array}$ & $\begin{array}{l}\text { Triglyceride } \\
(\mathbf{m g} / \mathbf{d l})\end{array}$ & Athrogenic index \\
\hline Group I & $69.81 \pm 0.51^{\mathrm{b}^{*}}$ & $23.67 \pm 0.43^{\mathrm{b}^{*}}$ & $46.14 \pm 0.6 \mathrm{~b}^{\mathrm{b}^{*}}$ & $155.87 \pm 0.24^{\mathrm{b}^{*}}$ & $78.57 \pm 0.20^{\mathrm{b}^{*}}$ & $2.90 \pm 0.08^{\mathrm{b}^{*}}$ \\
\hline Group II & $167.17 \pm 0.26^{\mathrm{a}^{*}}$ & $49.41 \pm 0.12^{\mathrm{a}^{*}}$ & $117.76 \pm 0.57^{7^{*}}$ & $208.33 \pm 0.33^{3^{*}}$ & $121.83 \pm 0.33^{\mathrm{a}^{*}}$ & $9.73 \pm 0.21^{\mathrm{a}^{*}}$ \\
\hline Group III & $77.43 \pm 0.29^{\mathrm{a}^{*}, \mathrm{~b}^{*}}$ & $24.36 \pm 0.74^{\mathrm{a}^{*}, \mathrm{~b}^{*}}$ & $53.07 \pm 0.82^{\mathrm{a}^{*}, \mathrm{~b}^{*}}$ & $160.71 \pm 0.34^{\mathrm{a}^{*}, \mathrm{~b}^{*}}$ & $84.03 \pm 0.40^{\mathrm{a}^{*}, \mathrm{~b}^{*}}$ & $3.35 \pm 0.18^{\mathrm{a}^{*}, \mathrm{~b}^{*}}$ \\
\hline Group IV & $72.74 \pm 0.47^{\mathrm{a}^{*}, \mathrm{~b}^{*}}$ & $23.05 \pm 0.40^{\mathrm{a}^{*}, \mathrm{~b}^{*}}$ & $49.69 \pm 0.22^{2^{*}, \mathrm{~b}^{*}}$ & $156.47 \pm 0.12^{\mathrm{a}^{*}, \mathrm{~b}^{*}}$ & $79.47 \pm 0.37^{\mathrm{a}^{*}, \mathrm{~b}^{*}}$ & $2.88 \pm 0.84^{\mathrm{a}^{*}, \mathrm{~b}^{*}}$ \\
\hline Group V & $72.92 \pm 0.22^{\mathrm{a}^{*}, \mathrm{~b}^{*}}$ & $23.44 \pm 0.55^{\mathrm{a}^{*}, b^{*}}$ & $49.48 \pm 0.56^{\mathrm{a}^{*}, \mathrm{~b}^{*}}$ & $156.29 \pm 0.28^{\mathrm{a}^{*}, \mathrm{~b}^{*}}$ & $80.19 \pm 0.07^{\mathrm{a}^{*}, \mathrm{~b}^{*}}$ & $2.97 \pm 0.53^{\mathrm{a}^{*}, \mathrm{~b}^{*}}$ \\
\hline
\end{tabular}

Values are expressed as mean \pm SE ( $\mathrm{n}=6$ rats); $P$ values: ${ }^{*}<0.001,{ }^{* *}<0.05$; NS: Non Significant; a $\rightarrow$ group I compared with groups II, III, IV, V; $\mathrm{b} \rightarrow$ group II compared with groups III, IV, V; Details of group I-V are same as in Table 1. 
Table 3 Effect of flavone from Mucuna pruriens and coumarin from lonidium suffruticosum on tissues ester cholesterol profile in control and experimental rats

\begin{tabular}{llll}
\hline Groups & \multicolumn{3}{l}{ Ester cholesterol $(\mathbf{m g} / \mathbf{g}$ tissue $)$} \\
\cline { 2 - 4 } & Liver & Heart & Aorta \\
\hline Group I & $0.67 \pm 0.02^{\mathrm{b}^{*}}$ & $2.86 \pm 0.01^{\mathrm{b}^{*}}$ & $2.02 \pm 0.42^{\mathrm{b}^{*}}$ \\
\hline Group II & $2.55 \pm 0.04^{\mathrm{a}^{*}}$ & $6.96 \pm 0.02^{\mathrm{a}^{*}}$ & $6.81 \pm 0.23^{\mathrm{a}^{*}}$ \\
\hline Group III & $2.02 \pm 0.01^{\mathrm{a}^{*}, \mathrm{~b}^{* *}}$ & $3.78 \pm 0.03^{\mathrm{a}^{*} \mathrm{~b}^{*}}$ & $4.98 \pm 0.24^{\mathrm{a}^{*}, \mathrm{~b}^{*}}$ \\
\hline Group IV & $2.59 \pm 0.03^{\mathrm{a}^{*}, \mathrm{~b}^{*}}$ & $3.10 \pm 0.01^{\mathrm{a}^{*}, \mathrm{~b}^{*}}$ & $2.69 \pm 0.09^{\mathrm{a}^{*}, \mathrm{~b}^{*}}$ \\
\hline Group V & $1.84 \pm 0.01^{\mathrm{a}^{*}, \mathrm{~b}^{*}}$ & $2.98 \pm 0.01^{\mathrm{a}^{*}, \mathrm{~b}^{*}}$ & $2.83 \pm 0.11^{\mathrm{a}^{*}, \mathrm{~b}^{*}}$
\end{tabular}

Values are expressed as mean $\pm \mathrm{SE}\left(\mathrm{n}=6\right.$ rats); $P$ values: ${ }^{*}<0.001,{ }^{* *}<0.05$; NS: Non Significant; $\mathrm{a} \rightarrow$ group I compared with groups II, III, IV, V; b $\rightarrow$ group II compared with groups III, IV, V; Details of group I-V are same as in Table 1.

had showed a significant $(\mathrm{p}<0.001)$ decrease in the total cholesterol level compared to HFD rats (group II). Lowering high cholesterol levels significantly reduced the risk of heart attacks, strokes, and death. However, the rats received coumarin (I. suffruticosum) at the dose of $10 \mathrm{mg} / \mathrm{kg}$ b.wt (Group IV) with HFD had showed restored the plasma cholesterol level near to normal as that of standard (Group V).

As shown in Tables 2, 3 and 4, the significant $(\mathrm{P}<0.001)$ increase in levels of both free and ester cholesterol were also observed in plasma and tissue of rats fed with high fat diet (group II) when compared to control rats (group I). This high cholesterol concentration in circulation may damage the endothelial cells lining the large arteries and aorta and this may be an initial event in the etiology of atherosclerosis [22]. Both plasma free and ester cholesterol reduced remarkably on treating the HFD rats with flavone (M. pruriens) and coumarin (I. suffruticosum) at the dose of $10 \mathrm{mg} / \mathrm{kg}$ body weight. This lipid lowering effect may be due to the inhibition of hepatic cholesterogenesis or due to the increase in excretion of fecal sterol [23].

As shown in Tables 2 and 5. The concentration of plasma and tissue triglyceride elevated in rats fed with high fat diet (group II) as compared to control rats

Table 4 Effect of flavone from Mucuna pruriens and coumarin from lonidium suffruticosum on tissues free cholesterol profile in control and experimental rats

\begin{tabular}{|c|c|c|c|}
\hline \multirow[t]{2}{*}{ Groups } & \multicolumn{3}{|c|}{ Free cholesterol (mg/g tissue) } \\
\hline & Liver & Heart & Aorta \\
\hline Group I & $0.65 \pm 0.01^{b^{*}}$ & $0.69 \pm 0.01^{b^{*}}$ & $0.40 \pm 0.01^{b^{*}}$ \\
\hline Group II & $1.24 \pm 0.01^{\mathrm{a}^{* *}}$ & $1.17 \pm 0.03^{a^{*}}$ & $1.86 \pm 0.02^{\mathrm{a}^{*}}$ \\
\hline Group III & $0.89 \pm 0.01^{a^{*}, b^{* *}}$ & $0.12 \pm 0.01^{a^{* *}, b^{*}}$ & $0.73 \pm 0.01^{1^{*}, b^{*}}$ \\
\hline Group IV & $0.73 \pm 0.01^{a^{*}, b^{*}}$ & $0.66 \pm 0.01^{a^{*}, b^{*}}$ & $0.62 \pm 0.01^{a^{*}, b^{*}}$ \\
\hline Group V & $0.81 \pm 0.04^{\mathrm{a}^{*}, \mathrm{~b}^{*}}$ & $0.64 \pm 0.04^{\mathrm{a}^{*}, \mathrm{~b}^{*}}$ & $0.63 \pm 0.04^{a^{*}, b^{*}}$ \\
\hline
\end{tabular}

Values are expressed as mean $\pm \mathrm{SE}\left(\mathrm{n}=6\right.$ rats); $P$ values: ${ }^{*}<0.001,{ }^{* *}<0.05$; NS: Non Significant; a $\rightarrow$ group I compared with groups II, III, IV, V; b $\rightarrow$ group II compared with groups III, IV, V; Details of group I-V are same as in Table 1.
Table 5 Effect of flavone from Mucuna pruriens and coumarin from lonidium suffruticosum on tissues Triglyceride level in control and experimental rats

\begin{tabular}{lccc}
\hline Groups & \multicolumn{4}{l}{ Triglyceride (mg/g tissue) } \\
\cline { 2 - 4 } & Liver & Heart & Aorta \\
\hline Group I & $7.95 \pm 0.01^{\mathrm{b}^{*}}$ & $9.17 \pm 0.01^{\mathrm{b}^{*}}$ & $9.48 \pm 0.33^{\mathrm{b}^{*}}$ \\
\hline Group II & $18.11 \pm 0.19^{\mathrm{a}^{*}}$ & $28.79 \pm 0.16^{\mathrm{a}^{*}}$ & $19.37 \pm 0.78^{\mathrm{a}^{*}}$ \\
\hline Group III & $9.57 \pm 0.15^{\mathrm{a}^{*}, \mathrm{~b}^{*}}$ & $16.78 \pm 0.21^{\mathrm{a}^{*}, \mathrm{~b}^{*}}$ & $12.67 \pm 0.11^{\mathrm{a}^{*}, \mathrm{~b}^{*}}$ \\
\hline Group IV & $8.24 \pm 0.10^{\mathrm{a}^{*}, \mathrm{~b}^{*}}$ & $15.47 \pm 0.12^{\mathrm{a}^{*}, \mathrm{~b}^{*}}$ & $12.08 \pm 0.12^{\mathrm{a}^{*}, \mathrm{~b}^{*}}$ \\
\hline Group V & $8.31 \pm 0.69^{\mathrm{a}^{*}, \mathrm{~b}^{*}}$ & $15.21 \pm 0.36^{\mathrm{a}^{*}, \mathrm{~b}^{*}}$ & $12.15 \pm 0.01^{\mathrm{a}^{*}, \mathrm{~b}^{*}}$
\end{tabular}

Values are expressed as mean $\pm \mathrm{SE}\left(\mathrm{n}=6\right.$ rats); $P$ values: ${ }^{*}<0.001,{ }^{* *}<0.05$; NS: Non Significant; a $\rightarrow$ group I compared with groups II, III, IV, V; b $\rightarrow$ group II compared with groups III, IV, V; Details of group I-V are same as in Table 1.

(group I). HFD rats had significant increase in the level of plasma triglyceride due to decrease in the activity of lipoprotein lipase [24,25]. Both plasma and tissue triglyceride levels were significantly reduced in rats treated with flavone (M. pruriens) at the dose of $10 \mathrm{mg} / \mathrm{kg}$ body weight, coumarin (I. suffruticosum) at the dose of $10 \mathrm{mg} / \mathrm{kg}$ body weight and as well as standard drug atorvastatin along with HFD when compared with rats fed with high fat diet (group II). Administration of coumarin (I. suffruticosum) at the dose of $10 \mathrm{mg} / \mathrm{kg}$ body weight reduced the triglyceride level significantly $(\mathrm{p}<0.001)$ in comparison with flavone ( $M$. pruriens). The flavone ( $M$. pruriens) and coumarin (I. suffruticosum) may have stimulation of lipoprotein lipase activities resulting in decrease of plasma triglyceride and might increase the uptake of triglyceride from plasma by skeletal muscle and adipose tissues [26].

As shown in Tables 2 and 6, the concentration of plasma and tissue phospholipids significantly increased in rats fed HFD (group II) as compared to control animals (group I). This may be due to decreased phospolipase activity [27]. (Group II). Both plasma and tissue phospholipids levels significantly decreased in rats treated with flavone (M. pruriens) $10 \mathrm{mg} / \mathrm{kg}$ body weight and coumarin (I. suffruticosum) $10 \mathrm{mg} / \mathrm{kg}$ body weight and as

Table 6 Effect of flavone from Mucuna pruriens and coumarin from lonidium suffruticosum on tissues Phospholipids level in control and experimental rats

\begin{tabular}{llll}
\hline Groups & \multicolumn{3}{l}{ Phospholipids (mg/g tissue) } \\
\cline { 2 - 4 } & Liver & Heart & Aorta \\
\hline Group I & $12.37 \pm 0.45^{\mathrm{b}^{*}}$ & $18.04 \pm 0.67^{\mathrm{b}^{*}}$ & $10.32 \pm 0.05^{\mathrm{b}^{*}}$ \\
\hline Group II & $25.14 \pm 0.69^{\mathrm{a}^{*}}$ & $26.47 \pm 0.10^{\mathrm{a}^{*}}$ & $17.45 \pm 0.29^{\mathrm{a}^{*}}$ \\
\hline Group III & $17.81 \pm 0.01^{1^{*}, \mathrm{~b}^{*}}$ & $20.14 \pm 0.65^{\mathrm{a}^{*}, \mathrm{~b}^{*}}$ & $13.06 \pm 0.13^{\mathrm{a}^{*}, \mathrm{~b}^{* *}}$ \\
\hline Group IV & $16.45 \pm 0.06^{\mathrm{a}^{*}, \mathrm{~b}^{*}}$ & $19.45 \pm 0.73^{\mathrm{a}^{*}, \mathrm{~b}^{*}}$ & $12.47 \pm 0.12^{\mathrm{a}^{*}, \mathrm{~b}^{*}}$ \\
\hline Group V & $17.45 \pm 0.77^{\mathrm{a}^{*}, \mathrm{~b}^{*}}$ & $19.08 \pm 0.18^{\mathrm{a}^{*}, b^{* *}}$ & $12.02 \pm 0.10^{\mathrm{a}^{*}, b^{*}}$ \\
\hline
\end{tabular}

Values are expressed as mean $\pm \mathrm{SE}\left(\mathrm{n}=6\right.$ rats); $P$ values: ${ }^{*}<0.001,{ }^{* *}<0.05 ; \mathrm{NS}$ : Non Significant; a $\rightarrow$ group I compared with groups II, III, IV, V; b $\rightarrow$ group II compared with groups III, IV, V; Details of group I-V are same as in Table 1. 
Table 7 Effect of flavone from Mucuna pruriens and coumarin from lonidium suffruticosum on plasma lipoprotein in control and experimental rats

\begin{tabular}{lccc}
\hline Groups & HDL cholesterol $(\mathbf{m g} / \mathbf{d l})$ & LDL cholesterol $(\mathbf{m g} / \mathbf{d l})$ & VLDL cholesterol $(\mathbf{m g} / \mathbf{d l})$ \\
\hline Group I & $24.04 \pm 0.16^{\mathrm{b}^{*}}$ & $30.06 \pm 0.41^{\mathrm{b}^{*}}$ & $15.71 \pm 0.10^{\mathrm{b}^{*}}$ \\
\hline Group II & $17.17 \pm 0.22^{\mathrm{a}^{*}}$ & $125.64 \pm 0.55^{\mathrm{a}^{*}}$ & $24.36 \pm 0.17^{\mathrm{a}^{*}}$ \\
\hline Group III & $23.11 \pm 0.12^{\mathrm{a}^{*}, \mathrm{~b}^{*}}$ & $37.52 \pm 0.37^{\mathrm{a}^{*}, \mathrm{~b}^{*}}$ & $16.80 \pm 0.20^{\mathrm{a}^{*}, \mathrm{~b}}$ \\
\hline Group IV & $25.27 \pm 0.19^{\mathrm{a}^{*}, \mathrm{~b}^{*}}$ & $31.58 \pm 0.08^{\mathrm{a}^{*}, \mathrm{~b}^{*}}$ & $15.89 \pm 0.18 \mathrm{a}^{\mathrm{a}^{*}, \mathrm{~b}^{*}}$ \\
\hline Group V & $24.51 \pm 0.26^{\mathrm{a}^{*}, \mathrm{~b}^{*}}$ & $32.37 \pm 0.19^{\mathrm{a}^{*}, \mathrm{~b}^{*}}$ & $16.04 \pm 0.03^{\mathrm{a}^{*}, \mathrm{~b}^{*}}$ \\
\hline
\end{tabular}

Values are expressed as mean $\pm \mathrm{SE}$ ( $\mathrm{n}=6$ rats); $P$ values: ${ }^{*}<0.001,{ }^{* *}<0.05 ;$ NS: Non Significant; a $\rightarrow$ group I compared with groups II, III, IV, V; $\mathrm{b} \rightarrow$ group II compared with groups III, IV, V; Details of group I-V are same as in Table 1.

well as standard drug atorvastatin along with HFD when compared with rats fed with high fat diet (group II). Whereas, the rats received coumarin (I. suffruticosum) at the dose of $10 \mathrm{mg} / \mathrm{kg}$ body weight (Group IV) exhibited significant reduction in triglyceride level in comparison with flavone (M. pruriens) (Group III). The reduced concentration of phospholipids may also be due to the enhanced activity of phospholipases [11].

Atherogenic Index (AI) indicates the deposition of foam cells or plaque or fatty infiltration or lipids in heart, coronaries, aorta, liver and kidney. The higher the AI, higher is the risk of above organs for oxidative damage. As shown in Table 2, the atherogenic index (TG/ HDL-C ratio) used to predict risk of $\mathrm{CHD}$ and marker of small, dense LDL-C (an atherogenic lipoprotein) $[28,29]$ were significantly reduced by the flavone from M.pruriens and coumarin from I.suffruticosum, indicating the beneficial effect of flavone and coumarin in cardiovascular diseases.

As shown in Table 7, the reduction in the HDL produced by the group of animals fed with HFD was significant $(\mathrm{P}<0.001)$ in comparison with group I animals. This result is highly significant in that low HDL-cholesterol is now considered as the most significant risk factor for atherosclerosis [30] (Brewer, 2004). However, the treatment with flavone isolated from Mucuna pruriens (Group III) and coumarin derivatives isolated from Ionidium suffruticosum (Group IV) had significantly increased the HDL-cholesterol level when compared to HFD rats (Group II). It has clearly been demonstrated that a relationship exists between increased concentration of HDL-C and decreased morbidity-and mortalityrate in cardiovascular patients [31].

As shown in Table 7, the elevated levels of LDL and VLDL-cholesterol in rats fed with HFD (group II) was significant $(\mathrm{P}<0.001)$ in comparison with control rats (group I). High cholesterol diet increased serum cholesterol and LDL-C level significantly. Clinical and epidemiological studies have proved that individuals with elevated LDL show an increased risk for cardiovascular diseases [32]. Treatment of flavone from M.pruriens (Group III) and coumarin from I.suffruticosum (Group IV) markedly reduced the level of plasma LDL- cholesterol and VLDL-cholesterol when compared to HFD rats (group II). In comparison of flavone from $\mathrm{Mu}$ cuna pruriens (Group III) and coumarin from Ionidium suffruticosum (Group IV) with HFD (Group II) rats, the coumarin from Ionidium suffruticosum (Group IV) was showed significant reduction on both LDL-cholesterol and VLDL-cholesterol than that of group III rats. Recent research has revealed that a 4-5\% decrease in LDLcholesterol results in a 5-10\% decrease in the occurrence of coronary heart disease (CHD) [33].

\section{Conclusion}

On the basis of the present investigation was observed as the Coumarin derivatives isolated from Ionidium suffruticosum had showed a better antihyperlipidemic activity in comparison with flavone isolated from Mucuna pruriens. The Coumarin derivatives isolated from Ionidium suffruticosum is beneficial in preventing hypercholesterolemic atherosclerosis and reducing risk factors for coronary artery disease.

\section{Competing interests}

No disclosures. There is no affiliation, financial agreement or any other involvement with any company.

\section{Authors' contributions}

DSK carried out the in vivo studies, designed the protocol of the study and drafted the manuscript. AKM participated in design and coordination of the study. All authors read and approved the final manuscript.

\section{Acknowledgements}

We are thanking to the Department of Pharmacy, Annamalai University for providing the necessary facilities for carrying out the research work.

Received: 6 July 2012 Accepted: 29 September 2012

Published: 2 October 2012

\section{References}

1. Middlemiss D, Watson SP: A medicinal chemistry case study: an account of an Angiotensin II antagonist drug discovery programme. Tetrahedron 1994, 50:13049-13080.

2. Javed I, Rahman ZU, Khan MZ, Muhammad F, Aslam B, lqbal Z, Sultan JI, Ahmad I: Antihyperlipidaemic efficacy of Trachyspermum ammi in albino rabbits. Acta. Vet. Brno 2009, 78:229-236.

3. Bhandari U, Grover JK, Sharma JN: Effect of indigenous drugs on changes in morphology and cholesterol level of aorta in early atherosclerotic progression. Hamdard Med 2002, 4:56-59.

4. Ballantyne CM, Blazing MA, Hunninghake DB, Davidson MH, Yuan Z, DeLucca P, Ramsey KE, Hustad CM, Palmisano J: Effect on high density lipoprotein cholesterol of maximum dose simvastatin and atorvastatin in 
patients with hypercholesterolemia: Results of the comparative HDL efficacy and safety study (CHESS). Am. Heart J 2003, 146:862-869.

5. Dhawan BN, Dubey MP, Mehrotra BN, Rastogi RP, Tandon JS: Screening of Indian plants for biological activity. Part 9. Ind J Expt Biol 1980, 18:594-06.

6. Hishika R, Shastry S, Shinde S, Guptal SS: Prliminary, Phytochemical and Anti-inflammatory Activity of seeds of Mucuna pruriens. Indian J. Pharmacol 1981, 13(1):97-98.

7. Das S, Dash SK, Padhy SN: Ethno botanical information from Orissa state, India. A Review of Journal of Human Ecology 2004, 14(3):227.

8. Kheraro J, Bouquet A: Plantes medicinales et toxiques de la cote d'voireHaute-Volta. Paris: Vigot Freres; 1950:170.

9. Puspangadan P, Atal CK: Ethnobotanical investigations in Kerala, Some primitive tribal of Western Ghats and their herbal medicine. J Ethnopharmacol 1984, 11:59-77.

10. Harborne JB: Phytochemical methods $11^{\text {th }}$ Edn. New York: Chapman \& Hall; 1984:4-5.

11. Kottai Muthu A, Sethupathy S, Manavalan R, Karar PK: Hypolipidemic effect of methanolic extract of Dolichos biflorus Linn in high fat diet fed rats. Ind.J.Exp.Biol 2005, 43:522-525.

12. Maruthappan V, Sakthi Shree K: Hypolipidemic activity of Haritaki (Terminalia chebula) in atherogenic diet induced hyperlipidemic rats. $J$ Adv Pharm Tech Res 2010, 1(2):29-235.

13. Waynforth BH: Injection techniques. Experimental and surgical techniques in the rats. London: Academic Press; 1980:3.

14. Freidewald WT, Levy RI, Frederickson DS: Estimation of the concentration of low density lipoprotein cholesterol in plasma without use of the preparative ultracentrifuge. Clin Chem 1972, 18:499-502.

15. Sperry WM, Webb M: Revision of cholesterol determination. J Biol Chem 1950, 187:97.

16. Folch J, Lees $\mathrm{M}$, Sloane GH: A simple method for the isolation and purification of total lipids from animals tissues. J Biol Chem 1957, 226:497.

17. Foster CS, Dunn O: Stable reagents for determination of serum triglyceride by a colorimetric Hantzsch condensation methods. Clin Chem 1973, 19:338.

18. Zilversmit B, Davis AK: Micro determination of plasma phospholipids by trichloroacetic acid precipitation 28:method. J Lab Clin Inv 1950, 35:155.

19. Pasquali R, Casimirri F: Clinical aspects of ephedrine in the treatment of obesity. Int J Obes Relt Metb Disord 1993, 17:65-68.

20. Vijaimohan K, Jainu M, Sabitha KE, Subramaniyam S, Anandhan C, Shyamala Devi CS: Beneficial effects of alpha linoleic acid rich flax seed oil on growth performance and hepatic cholesterol metabolism in high fat diet fed rat. Life Sci 2006, 79:448-454.

21. Mehta K, Balaraman R, Amin AH, Bafna PA, Gulati OD: Effects of fruits of Moringa oleifera on the lipid profile of normal and hypercholesterolemic rabbits. J Ethnopharmacol 2003, 86:191-195.

22. Hennig B, Chow CK: Lipid Peroxidation and endothelial Cell injury: Implication in atherosclerosis. Free Radic Biol Med 1998, 4(2):99.

23. Purohit A, Vyas KB: Antiatherosclerotic effect of flax lignin complex isolated from flax seed. Atherosclerosis 2006, 179:269-275.

24. Kavitha R, Nalini N: Hypolipidemic effect of green and red chilli extract in rats fed high fat diet. Med. Sci. Res 2001, 28:17-21.

25. Van Heek M, Zilversmith DB: Evidence for an inverse relation between plasma triglyceride and aortic cholesterol in the Coconut oil Cholesterol fed rabbit. Atherosclerosis 1988, 71:185-192.

26. El-Hazmi MA, Warsy AS: Evaluation of serum cholesterol and trigluceride levels in 1-6-year-old Saudi children. Jour of Trop Pediatrics 2001, 47:181-185.

27. Mirhadi SA, Sudarshan S: Effect of garlic supplementation to cholesterol rich diet on development of atherosclerosis in rabbit. Ind. J. Exp. Bio 1991, 29:162.

28. Hanak V, Munoz J, Teague J, Stanley A, Bittner V: Accuracy of the triglyceride to high-density lipoprotein cholesterol ratio for prediction of the low-density lipoprotein phenotype B. Am J Cardiol 2004, 94:219-222.

29. Packard C, Caslake M, Shepherd J: The role of small, dense low density lipoprotein (LDL): A new look. Int J Cardiol 2000, 74:S17-S22.

30. Brewer HB Jr: Increasing HDL cholesterol levels. New Eng J Med 2004, 350:1491-1494.

31. Franceschini G: Epidemiological evidence for high density lipoprotein cholesterol as a risk factor for coronary artery disease. Am J Cardiol 2001, $88: 9 \mathrm{~N}-13 \mathrm{~N}$.
32. Keevil JG, Cullen MW, Gangnon R, McBride PE, Stein JH: Implications of cardiac risk and low-density lipoprotein cholesterol distributions in the United States for the diagnosis and treatment of dyslipidemia: data from National Health and Nutrition Examination Survey 1999 to 2002. Circulation 2007, 115:1363-1370.

33. Katan MB, Grundy SM, Jones P, Law M, Miettinen T, Paoletti R: Efficacy and safety of plant stanols and sterols in the management of blood cholesterol levels. Mayo Clin Proc 2003, 78:965-978.

doi:10.1186/1476-511X-11-126

Cite this article as: Dharmarajan and Arumugam: Comparative evaluation of flavone from Mucuna pruriens and coumarin from lonidium suffruticosum for hypolipidemic activity in rats fed with high Fat diet. Lipids in Health and Disease 2012 11:126.

\section{Submit your next manuscript to BioMed Central and take full advantage of:}

- Convenient online submission

- Thorough peer review

- No space constraints or color figure charges

- Immediate publication on acceptance

- Inclusion in PubMed, CAS, Scopus and Google Scholar

- Research which is freely available for redistribution 